\title{
The Influence of Positive Organizations on Companies in the Era 4.0
}

\author{
Maria Yosefina Jira Bara \\ evinbara0501@gmail.com
}

\section{Preliminary:}

Nowadays, many companies need more capabilities in operating various existing digital devices. In the world of business understanding and the ability to digital devices are also very much needed, because understanding this understanding can help the business to be able to compete in the market. Not only understanding and abilities are needed, but psychological health conditions and optimal performance can also help to build a positive organization that has mutual bonds between employees that can be applied in the workplace. Organizational improvement is also one of the factors that can build and encourage harmonious relationships to create a psychologically healthy and comfortable organization that can grow continuously in the future. Employees in Indonesia need a global understanding of employees. The ability that is owned can bring benefits to the community through various developments that are carried out. Many companies are starting to move to online activities. According to the company, the existence of the internet generates many opportunities for the company. It should be noted that in general the Indonesian population at this time is connected to the internet. The more connected, the fewer costs incurred and can shorten the time, distance, and space.

It can be seen that many new companies have entered the market using all their agility and abilities to break through old competitors and want to create new markets that have not been thought of by competitors. Being the key to business is not only in technology but also in people. Technology can be bought, but for humans, it can't be the reason to recruit the wrong people can cause the company to go bankrupt. All of this wants to prove that a good organizational climate can have a good impact on the company in achieving company and organizational goals. In other words, the better the organizational climate that is formed, the better the relationship between management and employees for the company in achieving a company target. 


\section{Research methods :}

The research method used is descriptive qualitative. This method is used to want to know and understand the phenomenon of companies in Indonesia facing various technological disruptions, globalization, and a millennial lifestyle that focuses on managing human resources so that organizations can operate in a healthy, comfortable and sustainable manner. This research is also oriented towards several cases that have occurred in several companies involving various facts that are easy to understand and willing to try how to interpret various phenomena from business actors to the phenomena that occur.

This research method also uses analysis. The analysis used is comprehensive. Where this analysis uses primary data, secondary data, and literature studies with an emphasis on positive organizations. A positive organization is a fact that is formed socially from the environment through interactions to create individuals in the organization. This study uses 4 companies as samples to require arguments

\section{Results and Discussion :}

A company needs an organization that has positive values. It can be explained that a positive organization is an organization that can thrive and can work sustainably to achieve excellent and extraordinary growth from all aspects to create employees who can concentrate, focus on work, flow, engage, and feel attached. With a soul calling in producing meaningful souls. Creating a positive organization does not just appear and requires various stages that must be passed. The various stages must be started from the recruitment stage. After that, the development of interest, and continued with skills to achieve the ultimate goal of a career and perform well. Inadvertently it is necessary to conduct a cultural assessment. In addition to the three stages above, other steps can be done, namely good communication and measurement to determine how much compensation and benefits will be received by employees.

In facing the market, of course, in the business world, there is a lot of very tough competition. In this period, the company will take advantage of being able to look for employees who have good intelligence, are psychologically competent, and can develop socially well. To prove that the company has obtained the desired employees, it can be seen from the increase in sales volume and profits at the end of the year. There is a wave of disruption that will hit many 
companies in Indonesia. This wave was triggered by the development of digital technology and lifestyle changes that made managers and company owners aware. This is all seen when there is no more appropriate response in dealing with this wave. To overcome this, a positive organization is applied to serve as a human resource manager to become more flexible to continuously foster and guide leaders and employees by remembering that the success and failure of a company come from the behavior of its human resources.

PT. Bank Central Asia, Tbk .; PT. Garuda Indonesia, Tbk .; PT. Nutrifood Indonesia; and BPJS Manpower. The 4 companies apply four dimensions, including positive meaning, positive communication, positive relationships, and positive culture. In the company PT. NutriFood Indonesia and PT. Bank Central Asia, Tbk applies 4 positive organizational dimensions, including positive meaning, positive communication, positive relationships, and positive culture. At PT. Garuda Indonesia, Tbk can realize positive employee behavior and contribute greatly to the company. The level of employee engagement has increased from 2016 to 2017. BPJS manpower has experienced a high increase in satisfaction with service satisfaction. Human resource management must be directed to enable, empower, involve, and create experiences. The next stage that must be done is the ability to maintain teamwork to build synergy and unity in work to realize high honesty and responsibility.

\section{Conclusion:}

A company that can create a positive organization will be seen in the performance of its employees which can produce positive values that can support an increase in net income and can make it's employees stronger in facing any changes. A positive organization can also ensure that employees are its main asset. This proves that a work-life balance and reward system are urgently needed. 